\title{
1 Operationalizing Ecosystem Services for the Mitigation of Soil Threats: A
}

\section{Proposed Framework}

3

4 Gudrun Schwilch* ${ }^{a}$, Lea Bernet ${ }^{a}$, Luuk Fleskens ${ }^{b}$, Elias Giannakis ${ }^{c}$, Julia Leventon ${ }^{d}$, Teodoro

5 Marañón $^{e}$, Jane Mills ${ }^{f}$, Chris Short ${ }^{f}$, Jannes Stolte ${ }^{g}$, Hedwig van Delden ${ }^{h}$, Simone

6 Verzandvoort ${ }^{i}$

7

$8{ }^{a}$ Centre for Development and Environment CDE, University of Bern, Hallerstrasse 10, 3012

$9 \quad$ Bern, Switzerland, gudrun.schwilch@cde.unibe.ch

${ }^{b}$ Soil Physics and Land Management Group, Wageningen University, The Netherlands, and Sustainability Research Institute, School of Earth and Environment, University of Leeds, UK, luuk.fleskens@wur.nl

${ }^{c}$ Energy, Environment and Water Research Center, The Cyprus Institute, e.giannakis@cyi.ac.cy

${ }^{d}$ Faculty of Sustainability, Leuphana University, Lüneburg, Germany, and Sustainability Research Institute (SRI), School of Earth and Environment, University of Leeds, UK.

${ }^{e}$ Institute of Natural Resources and Agrobiology, CSIC, Seville, Spain, teodoro@irnase.csic.es

${ }^{f}$ Countryside and Community Research Institute, University of Gloucestershire, UK jmills@glos.ac.uk, cshort@glos.ac.uk

${ }^{g} \mathrm{NIBIO}$ - Norwegian Institute of Bioeconomy Research, Environment and Climate Division, jannes.stolte@nibio.no 
${ }^{h}$ Research Institute for Knowledge Systems, Maastricht, The Netherlands, and School of Civil, Environmental and Mining Engineering, The University of Adelaide, Australia, hvdelden@riks.nl

${ }^{i}$ Alterra - WUR, Wageningen, The Netherlands, simone.verzandvoort@wur.nl

* corresponding author

\section{Abstract}

Despite numerous research efforts over the last decades, integrating the concept of ecosystem services into land management decision-making continues to pose considerable challenges. Researchers have developed many different frameworks to operationalize the concept, but these are often specific to a certain issue and each have their own definitions and understandings of particular terms. Based on a comprehensive review of the current scientific debate, the EU FP7 project RECARE proposes an adapted framework for soil-related ecosystem services that is suited for practical application in the prevention and remediation of soil degradation across Europe. We have adapted existing frameworks by integrating components from soil science while attempting to introduce a consistent terminology that is understandable to a variety of stakeholders. RECARE aims to assess how soil threats and prevention and remediation measures affect ecosystem services. Changes in the natural capital's properties influence soil processes, which support the provision of ecosystem services. The benefits produced by these ecosystem services are explicitly or implicitly valued by individuals and society. This can influence decision- and policymaking at different scales, potentially leading to a societal response, such as improved land management. The proposed ecosystem services framework will be applied by the RECARE project in a transdisciplinary 
process. It will assist in singling out the most beneficial land management measures and in identifying trade-offs and win-win situations resulting from and impacted by European policies. The framework thus reflects the specific contributions soils make to ecosystem services and helps reveal changes in ecosystem services caused by soil management and policies impacting on soil. At the same time, the framework is simple and robust enough for practical application in assessing soil threats and their management with stakeholders at various levels.

Key words: ecosystem services, soil functions, soil threats, land management, decision support, Europe

\section{Highlights}

- Integrating ecosystem services into land management decision-making is a challenge.

- An adapted framework for soil-related ecosystem services is needed; we present one.

- It helps identify changes caused by soil management and policies impacting on soil.

- It will be used to single out the most beneficial land management measures.

- Consistent terminology and clarity enable practical application with stakeholders.

\section{Introduction}

The mitigation of soil threats - such as erosion, compaction, salinization, sealing, contamination, or the loss of organic matter, to name just a few - is an increasingly challenging task for the global community, especially in light of population growth and 
climate change. Productivity goals related to immediate human needs often negatively affect long-term environmental sustainability (Foley et al., 2011). The concept of ecosystem services describes the benefits people obtain from ecosystems (MEA, 2005) and is suitable to illustrate the dependence of human well-being on ecosystems. Considering ecosystem services is thus crucial when improving agricultural production systems in order to reduce yield gaps (Bennett et al., 2010; Bommarco et al., 2013). In addition, soils, being part of the natural capital, provide or contribute to a multitude of ecosystem services that range far beyond agricultural production. Without the ecosystem services provided by soils, for example, we would have no clean drinking water, nor adequate protection from floods. Nonetheless, the various values of soils are often underestimated (Robinson et al., 2014) and remain largely unrecognized.

Given the importance of soils, their protection has enormous significance for human wellbeing and our social and economic development. To date, however, land management planning and the implementation of practices to mitigate soil threats do not take sufficient account of ecosystem services provided by soils (MEA, 2005; Schulte et al. 2014, FAO and ITPS, 2015). Efforts to use soil sustainably and preserve its ecosystem services are at the core of the EU research project RECARE (Preventing and Remediating Degradation of Soils in Europe through Land Care, 2013-2018, www.recare-project.eu). To this end, RECARE aims to measure how soil ecosystem services are affected by degradation and conservation. RECARE is engaging with stakeholders in a transdisciplinary process to develop and select appropriate methods to measure, evaluate, communicate and negotiate the services we obtain from soils, with the ultimate aim of improving land management. This research process requires a sound understanding of the ecosystem services concept and the current scientific debate on the assessment and valuation of ecosystem services. A review of this debate and the 
creation of an adapted framework for operationalizing the ecosystem services concept for soil threats and land management lay the foundation for the project.

Despite various research activities around the world over the last decades, integrating the concept of ecosystem services into land management decision-making continues to pose considerable challenges, and a coherent approach to assessing and valuing ecosystem services is still lacking (de Groot et al., 2010). Many different frameworks have been developed to operationalize the concept, but these are often specific to a certain issue (e.g. biodiversity, water) or level (e.g. national) and each have their own definitions and understandings of particular terms. The task of an ecosystem services framework is to aid the identification of services, as well as their role, values, and trade-offs therein, in order to inform policy and land management decisions. This article reviews existing frameworks and approaches and proposes an adapted framework for soil-related ecosystem services that is suited for practical application in the prevention and remediation of soil degradation across Europe. After briefly introducing the emergence of the ecosystem services concept, we review and compare existing ecosystem services frameworks and evaluate their concepts and terminologies (Section 2). Section 3 focuses on soil aspects and on the contradictory use of soil functions versus ecosystem services, while reviewing the current state of the art and identifying knowledge gaps. We then evaluate existing approaches to monitor and value ecosystem services (Sections 4 and 5, respectively). Furthermore, we examine how the ecosystem services concept has been operationalized in research projects and land management in Europe so far (Section 6). Based on our review, we develop a framework for considering soil ecosystem services that is applicable to all soil threats and land management contexts (Sections 7 and 8), and reflect on how to operationalize this framework for practical application, particularly to support decision-making in preventing and remediating soil 
degradation in Europe (Section 9). We conclude with an outlook on how the new framework could support ongoing global efforts (Section 10).

\section{Comparing ecosystem services frameworks}

The ecosystem services concept is considered a useful tool to communicate and highlight the dependence of human well-being on ecosystems. It has the potential to bridge the gaps between ecological, economic, and social perspectives and enable sustainable resource management (Braat and de Groot, 2012). Its most recent definition as proposed by Braat and de Groot (2012, p. 5) states that 'Ecosystem services are the direct and indirect (flux of) contributions of ecosystems to human well-being.' The term 'ecosystem services' was first proposed in the early 1980s to increase public awareness about the negative consequences of biodiversity loss on human well-being (Ehrlich and Ehrlich, 1981; Mooney and Ehrlich, 1997).

Since the 1990s, the number of scientific papers addressing ecosystem services has increased exponentially (Vihervaara et al., 2010), with the focus expanding to include natural capital beyond biodiversity (Fisher et al., 2009). Economists recognized that ecosystems' contributions to human well-being were more wide-ranging than previously thought and thus heavily undervalued in decision-making (Braat and de Groot, 2012).

The release of the Millennium Ecosystem Assessment (MEA) (2003, 2005) finally led to broad recognition of the need to integrate ecosystem services in policy decision-making (Gómez-Baggethun et al., 2010). The potential of an ecosystem for providing ecosystem services depends on ecosystem functioning, which in turn depends on the ecosystem's 
biophysical structure (of which soils are a part) and on ecosystem processes (de Groot et al., 2010). The MEA defines four types of ecosystem services as summarized below:

(1) Provisioning services: products obtained from ecosystems, including food, fibre, fuel, land, water, medicinal, biochemical, genetic, and ornamental resources.

(2) Regulating services: benefits obtained from the regulation of ecosystem processes, including carbon sequestration, erosion control, flood protection, pollination, water purification, and waste management.

(3) Cultural services: non-material benefits that individuals obtain from ecosystems (through use and non-use), including spiritual, religious, and cultural heritage, as well as recreation, tourism, landscape, and amenity.

(4) Supporting services: services that are necessary for the production of all other ecosystem services, such as soil formation and retention, cycling processes, and habitat provision.

The identification and assessment of processes driving the degradation of ecosystem services directly (land use change, climate change, spread of exotic species, contamination, etc.) or indirectly (demographic change, socio-economic change, etc.) were recommended as a basis for decision-making (MEA, 2005).

Critics of the MEA's approach state that this classification mixes processes for achieving services (means) and the services themselves (ends) in the same categories; for example, water regulation is a process to achieve potable water (Wallace, 2007). To achieve practical applicability, operationalization frameworks need to distinguish between intermediate services (e.g. water regulation), final services (e.g. provision of clean water), and benefits (e.g. drinking water) (Boyd and Banzhaf, 2007; Fisher et al., 2009). In response to these criticisms, another large collaborative initiative, The Economics of Ecosystems and Biodiversity (TEEB) (TEEB, 2010), developed a new cascading framework that distinguishes 
between the biophysical structure, functions, services, benefits, and values (Figure 1). It was supported by the United Nations Environment Programme (UNEP) and the European Commission and many experts currently consider it the best available framework for ecologically-based social and economic decision-making (Braat and de Groot, 2012).

[Figure 1 approximately here]

TEEB recommends three steps to analyse and structure ecosystem valuation: 1) Identify and assess the full range of ecosystem services; 2) Estimate and demonstrate the value of ecosystem services; 3) Inventory and manage the values of ecosystem services and seek solutions to overcome their undervaluation. In a recent report about different approaches to value ecosystem services in Europe, Brouwer et al. (2013) concluded that 'one of the main findings is that there does not exist one single, standard “TEEB” method or approach' (p. 5). To reach the target set by the EU 2020 Biodiversity Strategy of valuating ecosystem services in Europe, the existing frameworks need to be further integrated and implemented (Brouwer et al., 2013).

Further clarification of existing ecosystem services frameworks is offered by the Common International Classification of Ecosystem Services (CICES) initiative, which developed from work on environmental accounting undertaken by the European Environment Agency (EEA) (Haines-Young and Potschin, 2013). The CICES views ecosystem services as arising from the interaction of biotic and abiotic processes, and refers specifically to the 'final' outputs or products from ecological systems - that is, the goods or services directly consumed or used by people. Following TEEB, the CICES recognizes these outputs as provisioning, regulating, and cultural services; it does not, however, cover the so-called 'supporting services' defined in the MEA. Instead, these are treated as part of the ecosystem's underlying structures and 
processes. This change of perspective is particularly relevant to soils and soil processes, given that the MEA classified them as supporting services. The latest version of the CICES (V4) has a five-level hierarchical structure consisting of sections, divisions, groups, classes, and class types. The highest level consists of the three familiar sections adopted from the MEA (see CICES V4, www.cices.eu). The CICES has the disadvantage of being based mainly in the natural sciences, leading to weak inclusion of social aspects, and it has become rather complex, with extensive use of specialized terminology. Nonetheless, it has contributed considerably to standardized naming of ecosystem services. The CICES also links up with efforts to determine standards in environmental accounting and to integrate ecosystem services into national accounting systems such as the System of Environmental-Economic Accounting (SEEA) (Edens and Hein, 2013).

The MEA, TEEB, the CICES, and subsequent initiatives have tried to clarify the jumble of terms in ecosystem services frameworks. Despite these efforts, a clear and generally accepted framework and agreement on terms is still lacking. For example, what TEEB refers to as an ecosystem's 'biophysical structure' is often called 'biophysical process' or 'biophysical property’ by other initiatives (Braat and de Groot, 2012; Maes et al., 2012; Müller and Burkhard, 2012; and others). Together with the ecosystem functions it supports or provides, this ecosystem side of the framework has also been named 'natural capital stocks' (Dominati et al., 2010) or 'ecosystem potential’ (Bastian et al., 2013; Haines-Young et al., 2012; Rutgers et al., 2012). On the human well-being side of the framework, TEEB suggests distinguishing between 'services', 'benefits' and (economic) 'value', while others refer to 'intermediate services' and 'final services' (Crossman et al., 2013) and highlight the distinction of services supply and demand. Some authors describe the 'services' in TEEB as 'provision', and 'benefits' as 'use/services', while 'value' is referred to as 'the importance or appreciation of a 
service'. This lack of a consistent typology and terminology has led to numerous terms - such as properties, processes, functions and services - being used interchangeably (Robinson et al., 2013). Without clarifying these terms and concepts, we risk losing sight of the basic premise of considering natural capital and processes separately from the services they support. One of the results of this review is thus the development of a framework with clearly defined and consistently used terms (see Section 7).

\section{Soil functions and ecosystem services}

Soil scientists have recently recognized the importance of the ecosystem services concept for the prevention and mitigation of soil degradation (Bouma, 2014). A focus on soils requires differentiating ecosystem services delivered specifically by soils from those that are provided more generally by land (of which soil is a part). To date, soil ecosystem services have often been valued only implicitly within those of land (Robinson et al., 2014). The ecosystem services concept legitimates soil conservation practices by illustrating the broad value of healthy soils, and it aids their evaluation regarding trade-offs. This insight has spurred efforts to incorporate the ecosystem services concept in soil policymaking (Breure et al., 2012; Robinson et al., 2012).

Within the soil science community, the ecosystem services framework is often used in conjunction with the concept of soil functions. This latter concept emerged in Europe in the early 1970s (Glenk et al., 2012) and was adopted to develop a proposal for the EU Soil Framework Directive, highlighting seven key soil functions (European Commission, 2006):

- Biomass production, including in agriculture and forestry

- Storing, filtering, and transforming nutrients, substances, and water

- Biodiversity pool, such as habitats, species, and genes

- Physical and cultural environment for humans and human activities 
- Source of raw materials

- Acting as carbon pool (store and sink)

- Archive of geological and archaeological heritage

However, the soil functions concept exists in many different forms. Blum (2005) categorized soil functions into 'ecological functions' and 'non-ecological functions', with ecological functions consisting of 'biomass production', 'protection of humans and the environment', and 'gene reservoir'. Non-ecological functions include 'physical basis of human activities', 'source of raw materials' and 'geogenic and cultural heritage'.

Soil functions are often used interchangeably with soil roles and soil ecosystem services, leading to different combinations of categories across the various lists. According to Jax (2005), the term 'function' is used in four main ways (see Glenk et al., 2012, p. 10):

- as a synonym for 'process';

- referring to the operation or function(ing) of a system;

- $\quad$ as a synonym for 'role'; and

- $\quad$ as a synonym for 'service'.

\section{In order to avoid confusion with the well-understood term of soil processes, we suggest using} 'soil function' in the sense of 'soil role'. The role or function of soils is to provide (ecosystem) services. Soil processes, by contrast, support this provision of ecosystem services and thus represent the capacity of an ecosystem to supply provisioning, regulating, and cultural services.

Dominati et al. (2010) pointed out that the existing literature on ecosystem services tends to focus exclusively on ecosystem services rather than holistically linking these services to the 
natural capital base in which they originate. Although soils are major suppliers of critical ecosystem services, soil-related ecosystem services are often not recognized, not well understood, and thus not incorporated into the ecosystem services frameworks. As a result, the link between soil natural capital and these ecosystem services is generally overlooked (Breure et al., 2012). Haygarth and Ritz (2009) suggested combining ecosystem services with soil functions that are relevant to soils and land use in the UK. They paired each of their identified 18 services with a related soil function. Dominati et al. (2010, p. 1860) suggested the following roles of soils in the provision of services:

- Fertility role

- Filter and reservoir role

- Structural role (i.e. physical support)

- Climate regulation role

- Biodiversity conservation role

- Resource role

These correspond roughly to the soil functions as presented by the European Commission (2006) above, and, in our view, overlap with what is generally considered ecosystem services. One aspect that might be added is the increasing awareness of cultural services.

Glenk et al. (2012) considered the following frameworks as the most comprehensive and as the ones most consistently classifying and describing the linkages between soil and its management and resulting impacts on ecosystem services: the ones proposed by Robinson and Lebron (2010), Dominati et al. (2010) and Bennett et al. (2010). Glenk et al.'s key message is that 'soil functions should be viewed as (bundles of) soil processes that are providing input into the delivery of (valued) final ecosystem services’ (p. 35). Robinson et al. (2013) propose an earth system approach to provide more visibility to soils and other 
compartments of the earth system in the supply chain for ecosystem services. Although this approach includes many valuable considerations and a useful focus on soils, its stock-flow model becomes rather complex for practical application.

\section{Measuring, Monitoring, and mapping ecosystem services}

Ecosystem services researchers have undertaken major efforts to quantify and measure ecosystem services. Considerable effort has been put into identifying the relevant indicators and ways of measuring them in order to map and quantify ecosystem services at different spatial and temporal scales. Changes in ecosystem services need to be identified and quantified as comprehensively as possible. The exclusion of some classes of services just because they are difficult to quantify and measure must be avoided (Braat and de Groot, 2012). Quantifying bundles of ecosystem services and recognizing interrelations between individual indicators within indicator sets, however, remains a major challenge when it comes to monitoring ecosystem services flows.

Müller and Burkhard (2012) made various suggestions on how to raise indicator quality, such as improving knowledge about relevant causal relations, recognizing interrelations between indicators, improving the transparency of indicator derivation strategies, finding case-specific optimal degrees of indictor aggregation, assessing indicator uncertainties, or estimating normative loading in the indicator set. Specific indicators are needed for each component of the ecosystem services framework. On the ecosystem side, property and function indicators also called state indicators - provide information about potential services of an ecosystem, while on the human well-being side, performance indicators provide information about how much of these potential services is actually provided and/or used (van Oudenhoven et al., 2012). 
A quantitative review of 153 regional ecosystem services case studies by Seppelt et al. (2011) concluded by highlighting four aspects that would help to ensure the scientific quality and holistic approach of further ecosystem services studies: (1) biophysical realism of ecosystem data and models; (2) consideration of local trade-offs; (3) recognition of off-site effects (i.e. ecosystem services provision at different scales); and (4) comprehensive but critical involvement of stakeholders in assessment studies. The holistic involvement of a variety of stakeholders makes it possible to assess who has what ability to benefit from services. This is important because trade-offs occur not only between services (Viglizzo et al., 2012) but also between beneficiaries (Horcea-Milcu et al., 2016).

A huge amount of research has focused on mapping ecosystem services, and the variety of approaches has triggered several review papers on the methodologies used (e.g. Burkhard et al., 2009; Eigenbrod et al., 2010; Maes et al., 2012; Crossman et al., 2013). Maes et al. (2012) found that provisioning ecosystem services can be mapped and quantified easily and directly, whereas most regulating, supporting, and cultural services are more difficult to locate and require proxies for their quantification. Additionally, these authors point out that the connection between the status of an ecosystem and the services it delivers is still poorly explored. This is particularly critical with regard to soil-related services, as soil status can be masked for a certain time (e.g. using fertilizer).

Most mapping approaches are applied at national or even continental scales, and they are mainly used to support decision-making on changes in land use rather than land management. However, adapting land management is often more feasible and hence more effective in mitigating soil threats than completely changing the land use.

Only few studies have quantified and measured ecosystem services specifically related to soil; among them are studies by Rutgers et al. (2012), Schulte et al. (2014), and Dominati et al. 
(2014). A preliminary method for the quantification of soil quality indicators on arable farms was developed by Rutgers et al. (2012). These researchers had land users and experts score various ecosystem service indicators for their importance and informative value and then calculated a final indicative score for each indicator. This process should not be confused with ecosystem services valuation (see Section 5), as it represents a preliminary step before assessing actual service provision (which in turn might be compared to a maximum ecological potential, resulting in a performance index, as done by Rutgers et al., 2012). Another effort to develop a method for the quantification of soil-related ecosystem services was undertaken by Dominati et al. (2014), who worked with a comprehensive list of proxies for each service and units for measuring them. This study omitted cultural services due to their non-biophysical nature and the related challenges of quantifying them. The use of proxies is often inevitable due to the complexity and number of ecosystem services, but it requires careful consideration. Eigenbrod et al. (2010) compared primary data for biodiversity, recreation, and carbon storage in the UK with land-cover-based proxies and found a poor data fit and potentially large errors associated with proxy data. They recommend investing in survey efforts rather than using poor-quality proxy data, and conclude that surveys can be more cost-effective in the end.

Agriculture and land management can have a direct influence on ecosystem properties, functions, and services. Van Oudenhoven et al. (2012) applied the stepwise cascade model proposed by Haines-Young and Potschin (2010) to a multifunctional rural landscape in the Netherlands, assessing land management effects without confusing ecosystem properties, functions, and services, and thus avoiding double-counting. They confirmed that function indicators are a 'subset or combination of ecosystem property indicators, as was earlier suggested by Kienast et al. (2009)’ (van Oudenhoven et al., 2012, p. 118). Differences in ecosystem services between land management systems offer potential for mitigating trade- 
offs by combining contrasting services in strategically designed landscape mosaics (Lavelle et al., 2014).

Due to methodological challenges, cultural ecosystem services are generally only roughly included in ecosystem services assessments. At the same time, many authors clearly underline the importance of these immaterial benefits, especially those of cultural landscapes (Plieninger et al., 2013; Chan et al., 2012; Paracchini et al., 2014). Plieninger et al. (2013) stressed that spatially explicit information on cultural ecosystem services - as perceived by the local population - provides the basis for developing sustainable land management strategies, including biodiversity conservation and cultural heritage preservation. Work done in the UK by Kenter et al. (2014) suggests that analysis of cultural ecosystem services can be developed using quantitative indicators and drawing on publicly available datasets, such as surveys of recreation usage. However, they also emphasize the importance of participatory and interpretative research techniques developed in the social sciences to assess and understand cultural ecosystem services in location- and community-based contexts.

\section{Valuing ecosystem services}

The ecosystem services concept is intrinsically connected to values. It aims to provide a link between the supply of nature's goods and services and how they are valued by society. Indeed, much emphasis has been placed on valuing ecosystem services, with the aim of demonstrating that markets fail to adequately reflect the full value society gives to ecosystem services and hence often co-drive the degradation of ecosystems. The large body of literature on ecosystem services valuation has consistently shown that non-market values nearly always outweigh market values (e.g. Ananda and Herath, 2003; Shiferaw and Holden, 1999), 
377 although ways in which the latter are derived are often contested. Four research traditions have investigated the valuation of ecosystem services to support better informed decisions:

1. One school stresses the need to convert all values in monetary figures. Although its proponents are mindful of various shortcomings, their rationale is that decision- and policymakers are more likely to appreciate the full value of nature if they are confronted with a single figure indicating the total economic value of all services of an ecosystem. Because such a figure is more difficult to provide for soils than for other ecosystem components, the significance of soils is underplayed. Prominent examples include Costanza et al.’s $(1997,2014)$ value of the earth's natural capital, as well as TEEB’s Ecosystem Service Valuation Database (de Groot et al., 2012; van der Ploeg and de Groot, 2010).

2. A second school regards markets as inherently unsuitable for valuing nature, and objects to expressing the value of ecosystems in monetary terms (e.g. Sagoff, 2008). Proponents of this tradition hold that decisions must take account of different value systems and multiple criteria for assessing value. Any attempt to express value in monetary terms would reduce the dimensions considered, weakening the potential to achieve sustainability (also referred to as 'weak sustainability', see e.g. Ayres et al., 2001).

3. A third school focuses more on operational difficulties to maximize the value of ecosystem services. Managing land to maximize one (bundle of) ecosystem services often requires sacrificing value derived from other ecosystem services. The ecosystem services concept is well-suited to studying such trade-offs between different ecosystem services. An important initiative based on this paradigm is the Natural Capital project with its InVEST methodology (Kareiva et al., 2011). 
4. A fourth, emerging school has an even stronger focus on values rather than valuation, and in this sense constitutes an extension of schools 2 and 3 above. In this school, ecosystem services are seen as part of the social-ecological system (Folke, 2006; Olsson et al., 2004). Values associated with ecological knowledge and understanding play an important role in the provision of bundles of ecosystem services, as do the social networks associated with them. They are considered important for developing resilience within social-ecological systems and ecosystem services (CGIAR Research Program on Water, Land and Ecosystems, 2014).

The valuation of ecosystem services is examined by a large body of ecological economics literature. Economic valuation is based on an anthropocentric approach and defines value based on individual preferences. This approach is typically taken by the first school described above. The Total Economic Value (TEV) framework captures the benefits derived from ecosystem services. The total economic value of any resource is the sum of use and non-use values (Figure 2).

[Figure 2 approximately here]

'Use value' involves interaction with the resource and is subdivided into 'direct use value' and 'indirect use value'. Direct use value relates to the use of natural resources in a consumptive (e.g. industrial water abstraction) or in a non-consumptive manner (e.g. tourism). From an ecosystem services perspective, direct use value is often associated with provisioning (e.g. agriculture) and cultural ecosystem services (e.g. recreation activity). Indirect use value relates to the role of natural resources in providing or supporting key ecosystem services (e.g. nutrient cycling, climate regulation, habitat provision). In ecosystem services terminology, indirect use value is frequently attached to regulating ecosystem services. 
'Non-use value' is associated with benefits derived from the knowledge that natural resources and aspects of the natural environment are being maintained. Non-use value can be split into two parts: (1) bequest value (associated with the knowledge that the area as a resource will be passed on to future generations), and (2) existence value (derived from the satisfaction of knowing that a resource continues to exist, regardless of use made of it now or in the future) (Figure 2). Some authors have distinguished a third type of non-use value: (3) altruistic value (derived from the knowledge that contemporaries can enjoy the goods and services related to an area) (Hein, 2010; Kolstad, 2000). Option value can be both use or non-use value, and it is not associated with current use of a resource but with the benefit of keeping open the option to make use of it in the future. Within overall valuation of nature, the question of valid components and methodologies for assessing non-use values has been particularly hotly debated.

The available approaches and methods for ecosystem services valuation can be categorized as follows: (1) direct market valuation approaches (e.g. approaches based on market price, costs, or production function); (2) revealed-preference approaches (e.g. travel cost method, hedonic pricing approach) and (3) stated-preference approaches (e.g. contingent valuation method, choice experiment model, group valuation) (Chee, 2004; Pascual et al., 2010). Encompassing the monetary values of ecosystem services provisioning in integrated economic tools such as cost-benefit analysis and cost-effectiveness analysis can be very useful in evaluating policy options (e.g. land management measures for prevention and restoration). However, the methods outlined above have been criticized for being too hypothetical in complex situations (Getzner et al., 2005). Efforts are now being made to develop more deliberative valuation techniques that enable more open and potentially more grounded outputs in complex situations by combining stated-preference approaches with increased deliberation between 
experts and/or users. These techniques' outputs are more culturally constructed and richer from a contextual point of view and potentially consider a wider range of ecosystem services within any given valuation (Kenter et al, 2014).

\section{How have European research projects operationalized the soil ecosystem services concept?}

A previous systematic review by Vihervaara et al. (2010) showed that in publications up to 2008, the ecosystem services concept had been underexplored in relation to soil quality and regulation compared with biodiversity, and in agricultural systems compared with watersheds and forestry. This can be explained by the concept's history (see Section 2). To assess more recent developments and understand how the ecosystem services concept is being developed in relation to soils, we did a rapid systematic review of current and recent (mainly post-2008) soil research projects. To this end, we searched Scopus on 22 April 2014 for papers containing the keywords 'ecosystem services' and 'soils'. The results were then narrowed down to 1,137 publications that also contained the keyword 'Europe'. Using titles and abstracts, the list was further narrowed down by excluding those that did not match the combination of all three search criteria. The text and acknowledgments of the remaining 200 papers were then scanned for mention of the projects that supported or funded the research. This resulted in a list of 50 projects. Exploring information available on the Internet, we identified a number of project characteristics that could be used to categorize and compare the projects; at the same time, we excluded a number of projects that did not meet the criteria or for which no information was available. This resulted in a total of 39 projects being categorized and compared (see Appendix A, Table A).

First, we categorized the projects according to how explicitly they addressed soil ecosystem services. Only eight projects focused specifically on soil ecosystem services. Examples 
472 include the SOIL SERVICE project that explicitly focuses on soil biodiversity, or SoilTrEc,

473 which focuses on soil processes in river catchments. The SmartSOIL project explicitly 474 examined soil ecosystem services driven by soil organic carbon (i.e. food production and 475 climate regulation). The project informed farmers, advisers, and policymakers about benefits, 476 drawbacks, and costs of land management practices that increase or sustain soil carbon. 477 Another 18 projects included soil ecosystem services more implicitly in their research, considering them as intermediary services contributing to the ecosystem services on which the 479 projects mainly focused. Many of these projects (e.g. RUBICODE, MULTAGRI, LIBERATION) focused on biodiversity and included soil in terms of its potential impact on

481 biodiversity and ecosystem services. 13 projects were categorized as hybrids somewhere in between the above two categories. We found that projects focusing specifically on soils are usually run by large consortia and funded by the European Commission or similar international funding agencies. There were also a number of projects funded by national agencies in an effort to establish research with a national focus (e.g. MOUNTLAND) or small research centres (e.g. FuturES). These tended to have quite a broad ecosystem services focus and were therefore attributed to the hybrid category.

Next, we categorized projects based on whether they focused more on baseline knowledge or more on management impacts. Of the 39 projects, 34 were found to be 'baseline' projects that seek to characterize ecosystem services and understand their relationships. They monitor ecosystem services, observing changes or impacts of changes on benefits or on other ecosystem services. Their aim is to build an understanding of which services exist, how they are linked or bundled through benefits, and what trade-offs and gains result from the prioritization of certain services. Much of the soil-focused research (including the work done by the SOIL SERVICE project) falls into this category. Similarly, 30 out of the 39 projects 
were categorized as 'management' projects that build on this baseline knowledge by studying how management interventions impact on ecosystem services. Management interventions usually involve physical changes, such the planting of trees to reduce erosion. 'Management' projects often contribute to 'baseline' projects by monitoring the ecosystem services affected by the intervention being assessed. Most projects in this category focus on biodiversity (e.g. MULTAGRI, AGFORWARD). They also predominantly focus on agricultural land and hence implicitly include soil ecosystem services, although these are rarely specifically examined.

Finally, we examined how closely projects were related to decision-making and policymaking. We found that 23 projects can be characterized as decision-making or policy research that seeks to aid the promotion of 'successful' ecosystem services management. Many of these projects designed tools to support land use decision-making (e.g. LandSFACTS); others proposed policy responses to promote the uptake of ecosystem services management initiatives or to prevent damage to ecosystem services. A third subset in this category consists of projects that explicitly seek to support payments for ecosystem services by valuing these ecosystem services. Most projects in this subset do not have soil ecosystem services as an explicit focus.

Regardless of whether projects focused on baseline or on management knowledge, or how closely they were related to decision-making, the majority of projects focused on individual ecosystem services or bundles of ecosystem services (e.g. those related to biodiversity). This means that they zoomed in on components of the soil system. As a result, they were unable to assess how the studied ecosystem services interacted with others in the context of a soil threat, or to consider trade-offs between bundles of ecosystem services. A notable exception is the SoilTrEC project, which takes a holistic approach to understanding soil processes in river 
catchments. The project notes the need for 'a clear operational framework to convey soils research within the ecosystem services approach’ (Robinson et al., 2013 p. 1032).

The baseline knowledge which is being generated by current projects provides empirical data on individual, or groups of, ecosystem services. It thus provides a useful basis for the subsequent development of management and policy approaches. Moreover, this baseline knowledge is supplemented by research that implicitly focuses on soil ecosystem services as intermediary services contributing to end services such as water regulation. However, there remains a research and conceptual gap in relation to fully operationalizing ecosystem services for the mitigation of soil threats. Aiming to fill this gap within the RECARE project, we have developed an adapted ecosystem services framework, which is outlined in the next section.

\section{Requirements of an adapted framework to operationalize ecosystem services for the} mitigation of soil threats

Although many ecosystem services frameworks have been developed over time, choosing one that is appropriate to operationalize ecosystem services for the mitigation of soil threats remains challenging. RECARE aims to assess, at various spatial scales, how soil processes and ecosystem services are affected by soil threats and by prevention and remediation measures. We plan to use the ecosystem services concept for communication with local stakeholders to identify the most beneficial land management measures, and with national and European policymakers to identify trade-offs and win-win situations resulting from, and/or impacted by, European policies. The chosen framework must therefore reflect and acknowledge the specific contributions of soils to ecosystem services, and it must be capable of distinguishing changes in ecosystem services due to soil management and policies impacting on soil. At the same time, it must be simple and robust enough for practical application with stakeholders at various levels. Our literature review and feedback from 
scientists and policymakers at various conferences clearly showed that there is a need for (1) a framework that focuses specifically on soil ecosystem services, (2) clarification of the terms used therein, and (3) practical applicability of this framework.

Our review of ecosystem services frameworks revealed that none of the existing frameworks fully suits these requirements. We identified three major challenges that need to be addressed when working with, and thus adapting, an ecosystem services framework within the RECARE project (as well as beyond):

- Linking ecosystem services to soils as well as to land management

- Ensuring that the framework can be used with stakeholders at various scales to assess and value services provided by soils and affected by land management (to mitigate soil threats)

- Ensuring that the framework is both scientifically robust and simple

These challenges outline the research gap which this paper aims to close by adapting existing ecosystem services frameworks. We started from the framework proposed by Braat and de Groot (2012), which we sought to complement with elements from more soil-specific recent suggestions, for example by Dominati et al. (2014) while attempting to introduce a consistent terminology that is understandable to a variety of stakeholders. This is in line with suggestions by authors such as Bouma, who stated that achievement of the UN Sustainable Development Goals will require more effective use of transdisciplinary approaches by soil scientists (Bouma, 2014). The adapted ecosystem services framework, presented in Figure 3, uses the following elements from existing frameworks:

- MEA (2005): major categories of ecosystem services

- TEEB (2010): subcategories of ecosystem services, but adapted and simplified 
- Haines-Young and Potschin (2010): cascade model

- Braat and de Groot (2012): main model structure and feedback loops in TEEB model

- SmartSOIL (Glenk et al., 2012): soil processes, benefits

- Van Oudenhoven et al. (2012): land management, driving forces, societal response

- Dominati et al. (2014): natural capital, with inherent and manageable properties of soil; external drivers as 'other driving forces', degradation processes as 'soil threats'

- CICES (2013) and Mapping and Assessment of Ecosystems and their Services (MAES) (Maes et al., 2013) were considered, but without taking elements.

[Figure 3 approximately here]

\section{The RECARE ecosystem services framework}

Like many other ecosystem services frameworks, the RECARE framework distinguishes between an ecosystem side and a human well-being side. Given that the RECARE project focuses on soil threats, soil threats are the starting point on the ecosystem side of the framework. Soil threats affect natural capital such as soil, water, vegetation, air, and animals, and are in turn influenced by these. Within the natural capital, the RECARE framework focuses in particular on soil and its properties, which it classifies into 'inherent' and 'manageable' properties. According to Dominati et al. (2014), inherent properties include slope, orientation, depth, clay types, texture, size of aggregates (subsoil), stoniness, strength (subsoil), subsoil pans, and subsoil wetness class; manageable properties include soluble phosphate, mineral nitrogen, soil organic matter, carbon content, temperature, $\mathrm{pH}$, land cover, macroporosity, bulk density, strength (topsoil), and size of aggregates (topsoil). However, this distinction between inherent and manageable soil properties is arguable: for example, stoniness and wetness class are simultaneously inherent and manageable, as stones can be 
591

592

593

594

595

596

597 within a local context.

598 [Table 1 approximately here]

599

600

601

602

603

604

605

606

607

to be synonymous with ecosystem services, we decided to omit the former term from our

611 framework. This will help to avoid confusion among readers associating the term with a

612

removed and wetness influenced; whereas some of the subsoil properties may only change after decades of management and are thus considered to be more clearly inherent. Similarly, temperature, bulk density, strength, and size of aggregates can theoretically be influenced by man, but are in practice difficult to manage. A number of these properties could thus be exchanged between the two lists presented in Table 1. This also depends on the type of soil being assessed and on its vertical structure, so a valid distinction might only be possible

Water, vegetation, and animal properties, in particular, are mostly manageable and have a considerable influence on soil processes and ecosystem services. Air influences soil processes through the exchange of gases and fine particles and is linked to soil threats through airborne pollutants and the direct emission from and/or capturing of greenhouses gases in soils. Air can be managed by adapting the land cover, land use, and land management. Some of these nonsoil properties are also listed in Table 1 , but the list is certainly not yet exhaustive. Application of the framework within RECARE will provide an opportunity for completing and refining the property lists.

The natural capital's properties enable or influence soil processes, while at the same time being affected by them. Soil processes represent the ecosystem's capacity to provide services; that is, they support the provision of ecosystem services. Because we consider soil functions different meaning (see Section 3). 
'Provisioning services' include biomass production, water production, the supply of raw materials, and the physical base; 'regulating and maintenance services' include air quality regulation, waste treatment, water regulation and retention, climate regulation, maintenance of soil fertility, erosion control, pollination, biological control, lifecycle maintenance, habitat, and gene pool protection; and 'cultural services' include the enabling of spiritual and aesthetic experiences, the provision of inspiration, and the representation of cultural heritage.

Ecosystem services may be utilized to produce benefits for individuals and the human society, such as food, drinking water, or hazard regulation. These benefits are explicitly or implicitly valued by individuals and society. The monetary and intrinsic values attached to these benefits can influence decision- and policymaking at different scales, potentially leading to a societal response. A deliberative process of negotiating different policy priorities within a multi-stakeholder forum makes it possible to achieve optimal societal value and sustainability. Individual (e.g. farmers') and societal decision- and policymaking strongly determine land management, which again affects soil threats and natural capital. Land management includes physical practices in the field (i.e. technologies), but also the ways and means (e.g. financial, material, legislative, educational) to implement these (i.e. approaches) (Liniger and Critchley, 2007; Schwilch et al., 2011). Technologies entail agronomic (e.g. no-till, intercropping), vegetative (e.g. tree planting, grass strips), structural (e.g. terraces, dams) or management measures (e.g. land use change, area closure, rotational grazing) that control soil and land degradation and enhance productivity. These measures are often combined to reinforce each other.

Red arrows in Figure 3 represent the key links relevant to soil threats and soil management decision-making. These links are the main focus of RECARE, the aim being to operationalize 
the ecosystem services concept for practical application in preventing and remediating degradation of soils in Europe through land care.

The RECARE framework can be illustrated by the following example, which will help readers understand the ideas behind the boxes and arrows in Figure 3: A land user's intensive ploughing (land management) of sloping land under conditions of increasingly erratic rainfall due to climate change, market pressure to produce more and at a predefined time, and the tradition of preparing a fine seedbed (other natural and human driving forces) causes soil erosion (soil threat). Among other things, this leads to reduced soil organic matter content in the topsoil, changed topsoil aggregates, and reduced soil cover (properties of the natural capital), which affects soil organic matter cycling, soil structure maintenance, and water cycling (soil processes). This may result in reduced production of biomass and reduced offsite water regulation (ecosystem services), causing a decline in yield and downstream flooding (benefits). The loss in crop production and the downstream damage are given a negative value by society, producers, and policymakers (value). This could be discussed in a multistakeholder deliberation process and result in incentives for good agricultural practice provided to land users by large agri-food corporates and/or the adjustment, improvement, or more effective implementation of policies to protect soil against erosion and maintain key ecosystem services (decision- and policymaking). This leads the land user to implement a notill practice (land management), which enhances soil organic matter, improves soil structure and cover, and thus successfully combats soil erosion (soil threat). From here we can go through the same parts of the framework again, which are now influenced in a positive way. However, it is important to take into account trade-offs. In this example, the implemented notill practice might increase soil pollution owing to the application of herbicide, leading to a trade-off between soil threats. Ideally, sustainable land management should simultaneously be 
the starting point in the framework and the main aim of its application. Ultimately, the aim of sustainable land management could imply taking precautionary measures to prevent soil threats from even emerging.

The RECARE framework also relates to the DPSIR framework (Smeets and Weterings, 1999) by viewing the driving forces ('driver'), including land management, as exerting 'pressure' on soil resources, manifested through soil threats. These change the properties of the natural capital ('status') and affect ecosystem services ('impact 1') and human well-being ('impact 2'). In response to both of these, society either changes its decision- and policymaking, or land users directly adapt their land management ('response'), depending on their willingness and ability. See also the article by Müller and Burkhard (2012), who suggest a similar link between the ecosystem services and DPSIR frameworks from an indicator-based perspective.

Stakeholders can only improve ecosystem services through land management if these services are 'manageable' for them. A small study in Australia assessed farmers' perceived ability to manage ecosystem services (Smith and Sullivan, 2014). Only soil health and shade/shelter were indicated as being highly manageable, with a high convergence in views. While shade/shelter was a specific issue of the area, soil health was the only ecosystem service for which farmers indicated being both highly vulnerable to its loss and able to influence it themselves.

Measuring desired and achieved improvements in ecosystem services and in their underlying soil processes requires the definition of indicators. A thorough review undertaken for the RECARE project (Stolte et al., 2016) presents indicators for each soil threat. These enable measuring the effects of soil threats and remediation measures based on key soil properties as well as biophysical (e.g. reduced soil loss) and socio-economic (e.g. reduced workload) impact indicators. In order for these indicators to be of use in operationalizing the ecosystem 
services framework, it has to be possible to associate changes in their values (i.e. in soil properties and processes) to impacts of prevention and remediation measures. This requires the indicators to be sensitive to small changes, but still sufficiently robust to prove changes and enable their association to land management.

\section{Operationalizing the RECARE ecosystem services framework}

The proposed new framework's output and the ways in which it can be put to use for decision-making at various spatial scales will be further developed during the next years of the RECARE project. The 17 RECARE case study sites across Europe with their diversity of soil threats and land use systems will serve as a laboratory for operationalizing the framework. Prevention and remediation measures were selected and are now being trialled in all case study sites, and the changes in manageable soil and other natural capital properties are being measured and quantified. An assessment of changes in soil processes and ecosystem services based on meaningful aggregation and inclusion of proxy indicators will provide a comprehensive appraisal of each measure's impact. This will include measurement of cultural ecosystem services, which have largely been under-represented in ecosystem services assessments so far. In order to guarantee practical applicability in decision-making, data collection will be limited to the information needed to assess the measures’ impacts. Evidence from these impact assessments will then feed into stakeholder assessments. Stakeholders will value the interventions' impacts on ecosystem services and then discuss and reflect on the methods and policy recommendations.

So far, researchers from all study sites have drafted examples of potential outcomes for their respective site. These include preliminary lists of expected changes in soil properties, affected soil processes, and their assumed impacts on ecosystem services for the different soil threats 
and prevention and remediation measures. Some consideration was also given to how the framework can be embedded into existing and new governance structures. Two examples are included here to illustrate the framework's operationalization: In the case of soil erosion as a result of degradation and abandonment of agricultural terraces in Cyprus, an interdisciplinary group of experts found that measures such as terrace rehabilitation, crop diversification, afforestation, and improved design and management of unpaved roads could affect a variety of ecosystem services. These services include water availability and quality (for households and irrigation), erosion regulation, flood prevention, hazard regulation, soil formation, cultural heritage, and recreation and tourism. The impacts arising from the selected land management options, together with the perceived importance of each service, form the basis for stakeholders' upcoming valuation of the relevant services and will lead to the evaluation of land management practices and the formulation of policy advice. At another site, in the Netherlands, dairy farmers created a foundation to finance and exchange knowledge on crop and soil management practices that maintain or increase soil organic matter. They found that undersowing of grass in maize fields resulted in improved root biomass and soil water holding capacity.

The ecosystem services provided and influenced by prevention and remediation measures are valued differently by different stakeholders. For this reason, RECARE aims to develop a methodology that enables stakeholders at the local and (sub-)national levels to determine and negotiate values in a deliberative process that is suitable for being embedded in local governance structures. Based on our review, we envisage using stated preference methods namely, contingent valuation - to elicit stakeholders' willingness to pay for the specified environmental changes, along with direct market valuation approaches. Cost-benefit analysis will be applied to assess whether a prevention measure is likely to be adopted and to inform policymaking. Other methods may be added following further assessment of existing 
valuation tools (for monetary and non-monetary valuation) and their suitability for adaptation to soil threat mitigation.

The main aim is to create a practical basis for decision support in soil management, which can be used by local stakeholders, such as land users, river catchment groups, advisory services, or companies, to select optimally suited soil management measures, and by local, regional, national, and supranational planners and private-sector actors to shape investments, publicprivate agreements, legislation, regulation policies, and subsidy schemes. The framework will also be used as a basis to develop an integrated model for assessing the impact of different planning and policy options on ecosystem services under various external conditions at different scales. To ensure scalability, ecosystem service assessments will be scaled up from the local to the regional, national, and supranational (European) levels using integrated assessment modelling approaches (van Delden et al., 2011, 2010) that enable costeffectiveness and cost-benefit analyses of land management measures, approaches, and policies (Fleskens et al., 2014).

\section{Conclusions}

The need for a soil-focused ecosystem services framework has been confirmed by the newly revised World Soil Charter (FAO, 2015), whose Principle \#10 states: 'Soil degradation inherently reduces or eliminates soil functions and their ability to support ecosystem services essential for human well-being. Minimizing or eliminating significant soil degradation is essential to maintain the services provided by all soils and is substantially more cost-effective than rehabilitating soils after degradation has occurred.' The UN Food and Agriculture Organization's (FAO’s) new definition of sustainable soil management will also incorporate the concept of ecosystem services. Moreover, the UN Sustainable Development Goals (SDGs) 
lists, as Sustainable Development Goal \#15, to 'protect, restore and promote sustainable use of terrestrial ecosystems, sustainably manage forests, combat desertification, and halt and reverse land degradation and halt biodiversity loss' (United Nations, 2015). Given this widespread recognition that soils play a key role in terrestrial ecosystems, the development of appropriate tools to promote sustainable soil management is more than timely. With the soilfocused ecosystem services framework proposed in this paper we intend to make a practical contribution.

\section{Acknowledgements}

The research leading to these results has received funding from the European Union Seventh Framework Programme (FP7/2007-2013) under grant agreement No. 603498 (RECARE project). The authors wish to thank all partners of RECARE for their useful feedback on the suggested ecosystem services framework during and after the plenary meeting in Padova in March 2015. We are also grateful for the inputs and feedback received during the RECARE 'Soil Threats and Ecosystem Services’ workshop in Wageningen in May 2014 and the Global Soil Week dialogue session in Berlin in April 2015. Finally, we thank Marlène Thibault of CDE for editing this article and the two anonymous reviewers for their helpful comments.

\section{References}

Ananda, J., Herath, G., 2003. Soil erosion in developing countries: a socio-economic appraisal. J. Environ. Manage. 68, 343-353. doi:10.1016/S0301-4797(03)00082-3

Ayres, R., Berrgh, J. van den, Gowdy, J., 2001. Strong Versus Weak Sustainability: Economics, Natural Sciences, and Consilience. Environ. Ethics 23, 155-168.

Bastian, O., Syrbe, R.-U., Rosenberg, M., Rahe, D., Grunewald, K., 2013. The five pillar EPPS framework for quantifying, mapping and managing ecosystem services. Ecosyst. Serv. 4, 1524. doi:10.1016/j.ecoser.2013.04.003

Bennett, L.T., Mele, P.M., Annett, S., Kasel, S., 2010. Examining links between soil management, soil health, and public benefits in agricultural landscapes: An Australian perspective. Agric. Ecosyst. Environ. 139, 1-12. doi:10.1016/j.agee.2010.06.017 
Blum, W.E.H., 2005. Functions of Soil for Society and the Environment. Rev. Environ. Sci. Biotechnol. 4, 75-79. doi:10.1007/s11157-005-2236-x

Bommarco, R., Kleijn, D., Potts, S.G., 2013. Ecological intensification: harnessing ecosystem services for food security. Trends Ecol. Evol. 28, 230-238. doi:10.1016/j.tree.2012.10.012

Bouma, J., 2014. Soil science contributions towards Sustainable Development Goals and their implementation: linking soil functions with ecosystem services. J. Plant Nutr. Soil Sci. 177, 111-120. doi:10.1002/jpln.201300646

Boyd, J., Banzhaf, S., 2007. What are ecosystem services? The need for standardized environmental accounting units. Ecol. Econ. 63, 616-626. doi:10.1016/j.ecolecon.2007.01.002

Braat, L.C., de Groot, R., 2012. The ecosystem services agenda:bridging the worlds of natural science and economics, conservation and development, and public and private policy. Ecosyst. Serv. 1, 4-15. doi:10.1016/j.ecoser.2012.07.011

Breure, A., De Deyn, G., Dominati, E., Eglin, T., Hedlund, K., Van Orshoven, J., Posthuma, L., 2012. Ecosystem services: a useful concept for soil policy making! Curr. Opin. Environ. Sustain. 4, 578-585. doi:10.1016/j.cosust.2012.10.010

Brouwer, R., Brander, L., Kuik, O., Papyrakis, E., Bateman, I., 2013. A synthesis of approaches to assess and value ecosystem services in the EU in the context of TEEB. Final Report. Institute for Environmental Studies, University of Amsterdam.

Burkhard, B., Kroll, F., Müller, F., 2009. Landscapes' Capacities to Provide Ecosystem Services - a Concept for Land-Cover Based Assessments. Landsc. Online 15, 1-22. doi:10.3097/LO.200915

CGIAR Research Program on Water, Land and Ecosystems (WLE), 2014. Ecosystem services and resilience framework. International Water Management Institute (IWMI). CGIAR Research Program on Water, Land and Ecosystems (WLE), Colombo, Sri Lanka.

Chan, K.M.A., Satterfield, T., Goldstein, J., 2012. Rethinking ecosystem services to better address and navigate cultural values. Ecol. Econ. 74, 8-18. doi:10.1016/j.ecolecon.2011.11.011

Chee, Y.E., 2004. An ecological perspective on the valuation of ecosystem services. Biol. Conserv. 120, 549-565. doi:10.1016/j.biocon.2004.03.028

Costanza, R., d’Arge, R., Groot, R. de, Farber, S., Grasso, M., Hannon, B., Limburg, K., Naeem, S., O'Neill, R.V., Paruelo, J., Raskin, R.G., Sutton, P., Belt, M. van den, 1997. The value of the world's ecosystem services and natural capital. Nature 387, 253-260. doi:10.1038/387253a0

Crossman, N.D., Burkhard, B., Nedkov, S., Willemen, L., Petz, K., Palomo, I., Drakou, E.G., MartínLopez, B., McPhearson, T., Boyanova, K., Alkemade, R., Egoh, B., Dunbar, M.B., Maes, J., 2013. A blueprint for mapping and modelling ecosystem services. Ecosyst. Serv. 4, 4-14. doi:10.1016/j.ecoser.2013.02.001

de Groot, R., Brander, L., van der Ploeg, S., Costanza, R., Bernard, F., Braat, L., Christie, M., Crossman, N., Ghermandi, A., Hein, L., Hussain, S., Kumar, P., McVittie, A., Portela, R., Rodriguez, L.C., ten Brink, P., van Beukering, P., 2012. Global estimates of the value of ecosystems and their services in monetary units. Ecosyst. Serv. 1, 50-61. doi:10.1016/j.ecoser.2012.07.005

de Groot, R.S., Alkemade, R., Braat, L., Hein, L., Willemen, L., 2010. Challenges in integrating the concept of ecosystem services and values in landscape planning, management and decision making. Ecol. Complex. 7, 260-272. doi:10.1016/j.ecocom.2009.10.006

Dominati, E., Mackay, A., Green, S., Patterson, M., 2014. A soil change-based methodology for the quantification and valuation of ecosystem services from agro-ecosystems: A case study of pastoral agriculture in New Zealand. Ecol. Econ. 100, 119-129. doi:10.1016/j.ecolecon.2014.02.008

Dominati, E., Patterson, M., Mackay, A., 2010. A framework for classifying and quantifying the natural capital and ecosystem services of soils. Ecol. Econ. 69, 1858-1868. doi:10.1016/j.ecolecon.2010.05.002

Edens, B., Hein, L., 2013. Towards a consistent approach for ecosystem accounting. Ecol. Econ. 90, 41-52. doi:10.1016/j.ecolecon.2013.03.003 
Ehrlich, P.R., Ehrlich, A.H., 1981. Extinction: the causes and consequences of the disappearance of species. Random House, New York.

Eigenbrod, F., Armsworth, P.R., Anderson, B.J., Heinemeyer, A., Gillings, S., Roy, D.B., Thomas, C.D., Gaston, K.J., 2010. The impact of proxy-based methods on mapping the distribution of ecosystem services. J. Appl. Ecol. 47, 377-385. doi:10.1111/j.1365-2664.2010.01777.x

European Commission, 2006. Proposal for a directive of the European Parliament and the council establishing a framework for the protection of soil amending directive 2004/35/EC.

FAO and ITPS, 2015. Status of the World's Soil Resources (SWSR) - Main Report. Food and Agriculture Organization of the United Nations and Intergovernmental Technical Panel on Soils, Rome, Italy.

Fisher, B., Turner, R.K., Morling, P., 2009. Defining and classifying ecosystem services for decision making. Ecol. Econ. 68, 643-653.

Fleskens, L., Nainggolan, D., Stringer, L.C., 2014. An Exploration of Scenarios to Support Sustainable Land Management Using Integrated Environmental Socio-economic Models. Environ. Manage. 54, 1005-1021. doi:10.1007/s00267-013-0202-x

Foley, J.A., Ramankutty, N., Brauman, K.A., Cassidy, E.S., Gerber, J.S., Johnston, M., Mueller, N.D., O'Connell, C., Ray, D.K., West, P.C., Balzer, C., Bennett, E.M., Carpenter, S.R., Hill, J., Monfreda, C., Polasky, S., Rockström, J., Sheehan, J., Siebert, S., Tilman, D., Zaks, D.P.M., 2011. Solutions for a cultivated planet. Nature 478, 337-342. doi:10.1038/nature10452

Folke, C., 2006. Resilience: The emergence of a perspective for social-ecological systems analyses. Glob. Environ. Change 16, 253-267. doi:10.1016/j.gloenvcha.2006.04.002

Getzner, M., Spash, C., Stagl, S., 2005. Alternatives for environmental valuation. Routledge.

Glenk, K., McVittie, A., Moran, D., 2012. Deliverable D3.1: Soil and Soil Organic Carbon within an Ecosystem Service Approach Linking Biophysical and Economic Data. SmartSOIL Report.

Gómez-Baggethun, E., de Groot, R., Lomas, P.L., Montes, C., 2010. The history of ecosystem services in economic theory and practice: From early notions to markets and payment schemes. Ecol. Econ. 69, 1209-1218. doi:10.1016/j.ecolecon.2009.11.007

GSP, 2015. Revised World Soil Charter.

Haines-Young, R.H., Potschin, M.B., 2013. Common International Classification of Ecosystem Services (CICES): Consultation on Version 4, August-December 2012. EEA Framework Contract No EEA/IEA/09/003.

Haines-Young, R., Potschin, M., 2010. Proposal for a Common International Classification of Ecosystem Goods and Services (CICES) for Integrated Environmental and Economic Accounting. Report to the European Environment Agency.

Haines-Young, R., Potschin, M., Kienast, F., 2012. Indicators of ecosystem service potential at European scales: Mapping marginal changes and trade-offs. Ecol. Indic. 21, 39-53. doi:10.1016/j.ecolind.2011.09.004

Haygarth, P.M., Ritz, K., 2009. The future of soils and land use in the UK: Soil systems for the provision of land-based ecosystem services. Land Use Policy 26, Supplement 1, S187-S197. doi:10.1016/j.landusepol.2009.09.016

Hein, L., 2010. Economics and ecosystems: efficiency, sustainability and equity in ecosystem management. Edward Elgar Publishing Limited, Cheltenham, UK.

Horcea-Milcu, A.-I., Leventon, J., Hanspach, J., Fischer, J., 2016. Disaggregated contributions of ecosystem services to human well-being: a case study from Eastern Europe. Reg. Environ. Change 1-13. doi:10.1007/s10113-016-0926-2

Jax, K., 2005. Function and "functioning" in ecology: what does it mean? Oikos 111, 641-648. doi:10.1111/j.1600-0706.2005.13851.x

Kareiva, P.M., Tallis, H., Ricketts, T.H., Daily, G.C., Polasky, S., 2011. Natural Capital: Theory and Practice of Mapping Ecosystem Services. Oyford University Press. 
Kenter, J.O., Reed, M.S., Irvine, K.N., O’Brien, E., Brady, E., Bryce, R., Christie, M., Church, A., Cooper, N., Davies, A., Hockley, N., Fazey, I., Jobstvogt, N., Molloy, C., Orchard-Webb, J., Ravenscroft, N., Ryan, M., Watson, V., 2014. UK National Ecosystem Assessment Follow-on. Work Package Report 6: Shared, Plural and Cultural Values of Ecosystems. UNEP-WCMC, LWEC, UK.

Kienast, F., Bolliger, J., Potschin, M., Groot, R.S. de, Verburg, P.H., Heller, I., Wascher, D., HainesYoung, R., 2009. Assessing Landscape Functions with Broad-Scale Environmental Data: Insights Gained from a Prototype Development for Europe. Environ. Manage. 44, 1099-1120. doi:10.1007/s00267-009-9384-7

Kolstad, C., 2000. Environmental Economics. Oxford University Press, New York/Oxford.

Lavelle, P., Rodríguez, N., Arguello, O., Bernal, J., Botero, C., Chaparro, P., Gómez, Y., Gutiérrez, A., Hurtado, M. del P., Loaiza, S., Pullido, S.X., Rodríguez, E., Sanabria, C., Velásquez, E., Fonte, S.J., 2014. Soil ecosystem services and land use in the rapidly changing Orinoco River Basin of Colombia. Agric. Ecosyst. Environ. 185, 106-117. doi:10.1016/j.agee.2013.12.020

Liniger, H., Critchley, W. (Eds.), 2007. Where the land is greener. Case studies and analysis of soil and water conservation initiatives worldwide. World Overview of Conservation Approaches and Technologies (WOCAT), Bern.

Maes, J., Egoh, B., Willemen, L., Liquete, C., Vihervaara, P., Schägner, J.P., Grizzetti, B., Drakou, E.G., Notte, A.L., Zulian, G., Bouraoui, F., Luisa Paracchini, M., Braat, L., Bidoglio, G., 2012. Mapping ecosystem services for policy support and decision making in the European Union. Ecosyst. Serv. 1, 31-39. doi:10.1016/j.ecoser.2012.06.004

Maes, J., Hauck, J., Paracchini, M.L., Ratamäki, O., Hutchins, M., Termansen, M., Furman, E., PérezSoba, M., Braat, L., Bidoglio, G., 2013. Mainstreaming ecosystem services into EU policy. Curr. Opin. Environ. Sustain. 5, 128-134. doi:10.1016/j.cosust.2013.01.002

MEA, 2005. Ecosystems and Human Well-Being: Synthesis. Island Press, Washington DC.

MEA, 2003. Ecosystems and human well-being: a framework for assessment. Island Press, Washington, DC.

Mooney, H.A., Ehrlich, P.R., 1997. Ecosystem Services: a Fragmentary History., in: Daily, G. (Ed.), Nature's Services: Societal Dependence on Natural Ecosystems. Island Press, Washington DC, pp. 11-19.

Müller, F., Burkhard, B., 2012. The indicator side of ecosystem services. Ecosyst. Serv. 1, 26-30. doi:10.1016/j.ecoser.2012.06.001

Olsson, P., Folke, C., Berkes, F., 2004. Adaptive co-management for building social-ecological resilience. Environ. Manage. 34, 75-90.

Paracchini, M.L., Zulian, G., Kopperoinen, L., Maes, J., Schägner, J.P., Termansen, M., Zandersen, M., Perez-Soba, M., Scholefield, P.A., Bidoglio, G., 2014. Mapping cultural ecosystem services: A framework to assess the potential for outdoor recreation across the EU. Ecol. Indic. 45, 371385. doi:10.1016/j.ecolind.2014.04.018

Pascual, U., Muradian, R.,, Brander, L., Gómez-Baggethun, E., Martín-López, B., Verma, M., Armsworth, P., Christie, M., Cornelissen, H., Eppink, F., Farley, J., Loomis, J., Pearson, L., Perrings, C., Polasky, S., 2010. The economics of valuing ecosystem services and biodiversity, in: The Economics of Ecosystems and Biodiversity: Ecological and Economic Foundations. Routledge, New York, pp. pp. 183-256.

Plieninger, T., Dijks, S., Oteros-Rozas, E., Bieling, C., 2013. Assessing, mapping, and quantifying cultural ecosystem services at community level. Land Use Policy 33, 118-129. doi:10.1016/j.landusepol.2012.12.013

Robinson, D.A., Fraser, I., Dominati, E., Davíđsdóttir, B., Jónsson, J.O.G., Jones, L., Jones, S.B., Tuller, M., Lebron, I., Bristow, K.L., Souza, D.M., Banwart, S., Clothier, B.E., 2014. On the Value of Soil Resources in the Context of Natural Capital and Ecosystem Service Delivery. Soil Sciience Soc. Am. J. 78, 685-700. 
Robinson, D.A., Hockley, N., Cooper, D.M., Emmett, B.A., Keith, A.M., Lebron, I., Reynolds, B., Tipping, E., Tye, A.M., Watts, C.W., Whalley, W.R., Black, H.I.J., Warren, G.P., Robinson, J.S., 2013. Natural capital and ecosystem services, developing an appropriate soils framework as a basis for valuation. Soil Biol. Biochem. 57, 1023-1033. doi:10.1016/j.soilbio.2012.09.008

Robinson, D.A., Hockley, N., Dominati, E., Lebron, I., Scow, K.M., Reynolds, B., Emmett, B.A., Keith, A.M., de Jonge, L.W., Schjønning, P., Moldrup, P., Jones, S.B., Tuller, M., 2012. Natural Capital, Ecosystem Services, and Soil Change: Why Soil Science Must Embrace an Ecosystems Approach. Vadose Zone J. 11, 0. doi:10.2136/vzj2011.0051

Robinson, D.A., Lebron, I., 2010. On the natural capital and ecosystem services of soils. Ecol. Econ. 70, 137-138. doi:10.1016/j.ecolecon.2010.08.012

Rutgers, M., van Wijnen, H.J., Schouten, A.J., Mulder, C., Kuiten, A.M.P., Brussaard, L., Breure, A.M., 2012. A method to assess ecosystem services developed from soil attributes with stakeholders and data of four arable farms. Sci. Total Environ. 415, 39-48. doi:10.1016/j.scitotenv.2011.04.041

Sagoff, M., 2008. On the Economic Value of Ecosystem Services. Environ. Values 17, 239-257. doi:10.3197/096327108X303873

Schulte, R.P.O., Creamer, R.E., Donnellan, T., Farrelly, N., Fealy, R., O'Donoghue, C., O'hUallachain, D., 2014. Functional land management: A framework for managing soil-based ecosystem services for the sustainable intensification of agriculture. Environ. Sci. Policy 38, 45-58. doi:10.1016/j.envsci.2013.10.002

Schwilch, G., Bestelmeyer, B., Bunning, S., Critchley, W., Herrick, J., Kellner, K., Liniger, H. p., Nachtergaele, F., Ritsema, C. j., Schuster, B., Tabo, R., van Lynden, G., Winslow, M., 2011. Experiences in monitoring and assessment of sustainable land management. Land Degrad. Dev. 22, 214-225. doi:10.1002/ldr.1040

Seppelt, R., Dormann, C.F., Eppink, F.V., Lautenbach, S., Schmidt, S., 2011. A quantitative review of ecosystem service studies: approaches, shortcomings and the road ahead. J. Appl. Ecol. 48, 630-636. doi:10.1111/j.1365-2664.2010.01952.x

Shiferaw, B., Holden, S., 1999. Soil Erosion and Smallholders' Conservation Decisions in the Highlands of Ethiopia. World Dev. 27, 739-752. doi:10.1016/S0305-750X(98)00159-4

Smeets, E., Weterings, R., 1999. Environmental indicators: Topology and overview. European Environment Agency, Copenhagen.

Smith, H.F., Sullivan, C.A., 2014. Ecosystem services within agricultural landscapes-Farmers' perceptions. Ecol. Econ. 98, 72-80. doi:10.1016/j.ecolecon.2013.12.008

Smith, M., de Groot, R.S., Perrot-Maitre, D., Bergkamp, G., 2006. Establishing payments for watershed services. IUCN, Gland.

Stolte, J., Tesfai, M., Øygarden, L., Kværn $\varnothing$, S., Keizer, J., Verheijen, F., Panagos, P., Ballabio, C., Hessel, R., 2016. Soil threats in Europe (No. EUR 27607 EN), JRC Technical Reports.

TEEB, 2010. The Economics of Ecosystem and Biodiversity (TEEB): Ecological and Economic Foundations. Earthscan, London.

United Nations, 2015. Proposal for Sustainable Development Goals.

van Delden, H., Seppelt, R., White, R., Jakeman, A.J., 2011. A methodology for the design and development of integrated models for policy support. Environ. Model. Softw., Thematic issue on the assessment and evaluation of environmental models and software 26, 266-279. doi:10.1016/j.envsoft.2010.03.021

van Delden, H., Stuczynski, T., Ciaian, P., Paracchini, M.L., Hurkens, J., Lopatka, A., Shi, Y., Prieto, O.G., Calvo, S., van Vliet, J., Vanhout, R., 2010. Integrated assessment of agricultural policies with dynamic land use change modelling. Ecol. Model., Model-based Systems to Support Impact Assessment - Methods, Tools and Applications 221, 2153-2166. doi:10.1016/j.ecolmodel.2010.03.023 
van der Ploeg, S., de Groot, R.S., 2010. The TEEB Valuation Database - a searchable database of 1310 estimates of monetary values of ecosystem services. Foundation for Sustainable Development, Wageningen, the Netherlands.

van Oudenhoven, A.P.E., Petz, K., Alkemade, R., Hein, L., de Groot, R.S., 2012. Framework for systematic indicator selection to assess effects of land management on ecosystem services. Ecol. Indic. 21, 110-122. doi:10.1016/j.ecolind.2012.01.012

Viglizzo, E.F., Paruelo, J.M., Laterra, P., Jobbágy, E.G., 2012. Ecosystem service evaluation to support land-use policy. Agric. Ecosyst. Environ. 154, 78-84. doi:10.1016/j.agee.2011.07.007

Vihervaara, P., Rönkä, M., Walls, M., 2010. Trends in ecosystem service research: early steps and current drivers. Ambio 39, 314-324.

Wallace, K.J., 2007. Classification of ecosystem services: Problems and solutions. Biol. Conserv. 139, 235-246. doi:10.1016/j.biocon.2007.07.015 


\begin{tabular}{|c|c|c|}
\hline \multicolumn{3}{|c|}{ Properties of the natural capital } \\
\hline \multirow[t]{2}{*}{ Soil } & Inherent & $\begin{array}{l}\text { Slope } \\
\text { Orientation } \\
\text { Depth } \\
\text { Clay types } \\
\text { Texture } \\
\text { Temperature } \\
\text { Size of aggregates (subsoil) } \\
\text { Strength (subsoil) } \\
\text { Subsoil pans }\end{array}$ \\
\hline & Manageable & $\begin{array}{l}\text { Soluble phosphate } \\
\text { Mineral nitrogen } \\
\text { Soil organic matter } \\
\text { Carbon content } \\
\text { Soil moisture (topsoil) } \\
\text { Subsoil wetness class } \\
\mathrm{pH} \\
\text { Chemical quality } \\
\text { Stoniness } \\
\text { Cover (stones, litter, vegetation, etc.) } \\
\text { Macroporosity } \\
\text { Bulk density } \\
\text { Strength (topsoil) } \\
\text { Size of aggregates (topsoil) }\end{array}$ \\
\hline Water & Manageable & $\begin{array}{l}\text { Irrigation } \\
\text { Drainage } \\
\text { Groundwater depth } \\
\text { Surface water/runoff } \\
\text { Chemical quality } \\
\end{array}$ \\
\hline Vegetation & Manageable & $\begin{array}{l}\text { Cover } \\
\text { Vertical structure (e.g. multi-story) } \\
\text { Horizontal structure (e.g. patchiness, strips) } \\
\text { Species composition } \\
\text { Soil flora }\end{array}$ \\
\hline Animals & Manageable & $\begin{array}{l}\text { Amount (grazing pressure) } \\
\text { Type composition } \\
\text { Soil fauna and microorganisms }\end{array}$ \\
\hline \multirow[t]{2}{*}{ Air } & Inherent & $\begin{array}{l}\text { Temperature } \\
\text { Humidity }\end{array}$ \\
\hline & Manageable & Chemical quality \\
\hline
\end{tabular}




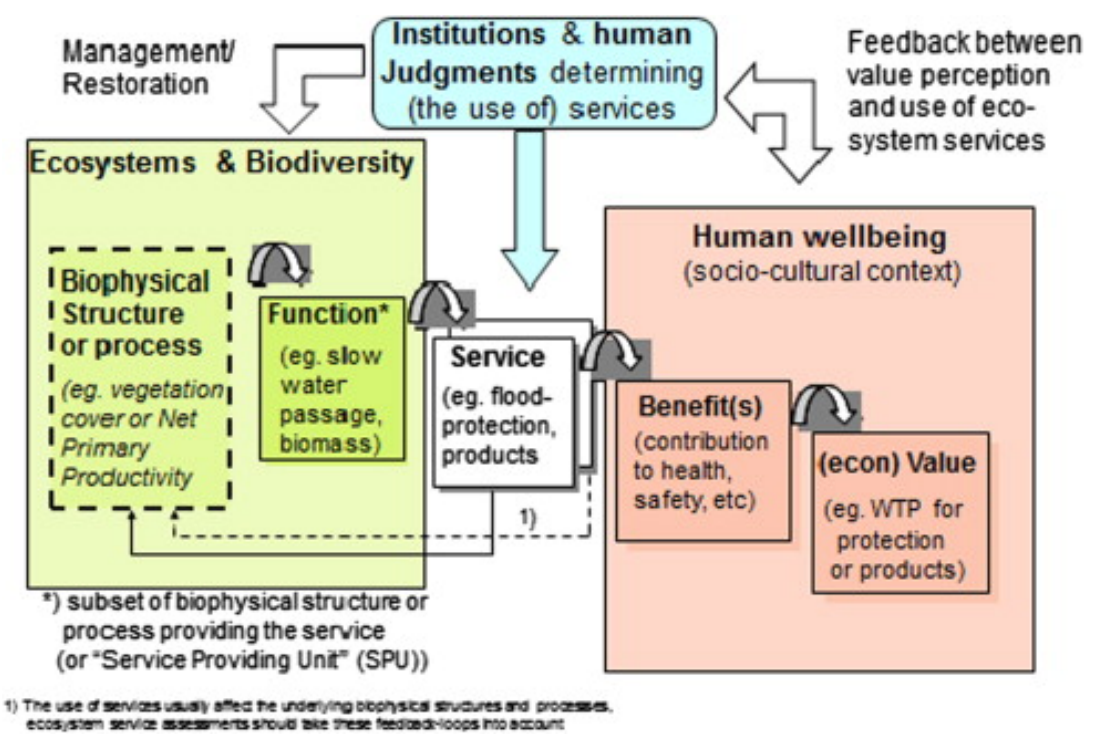

Figure 1: Overview of the framework developed by The Economics of Ecosystems and Biodiversity (TEEB). Designed for the purpose of economic valuation, this framework focuses mainly on economic values, without considering other value systems. Source: Braat and de Groot (2012), adapted from Haines-Young and Potschin (2009).

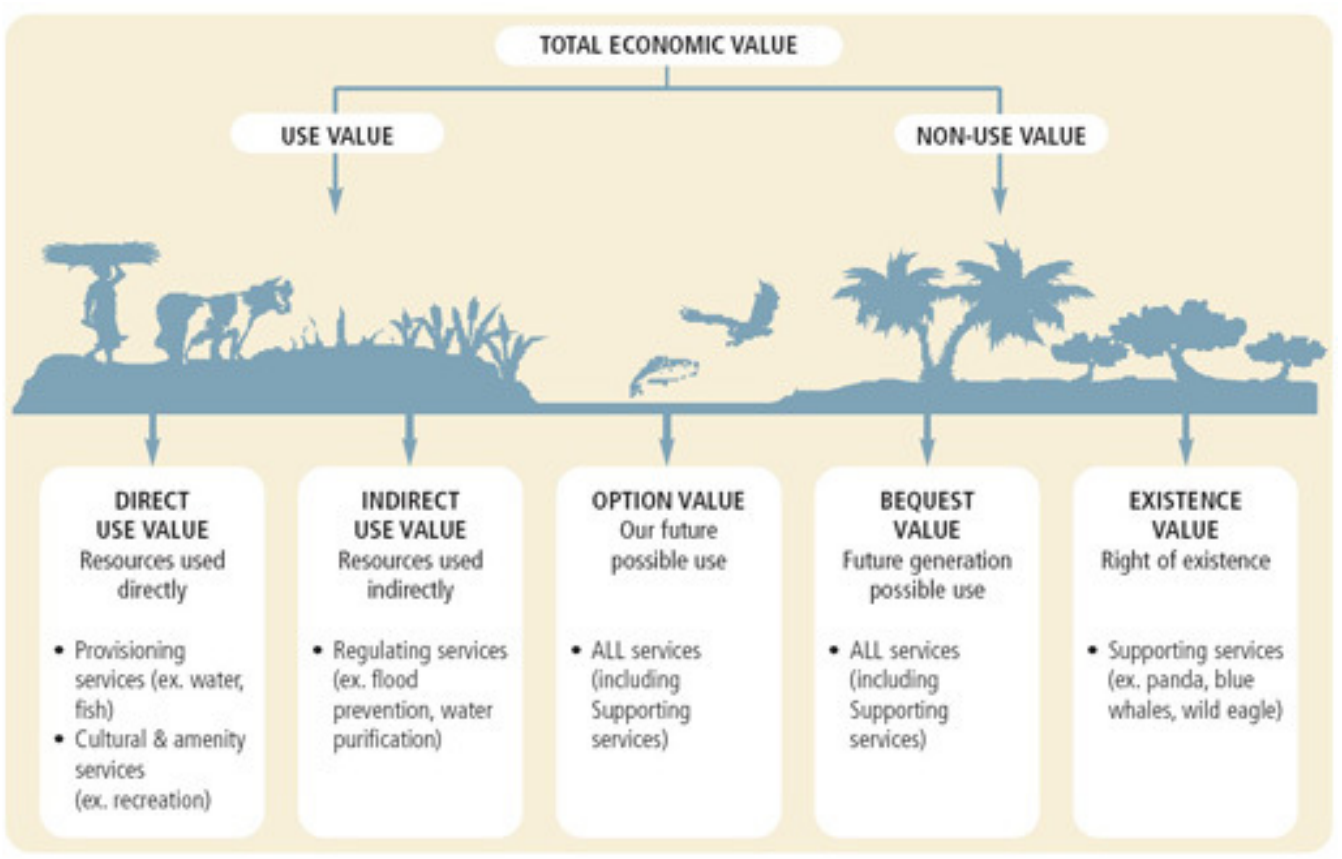

Figure 2. Overview of the Total Economic Value (TEV) of ecosystems (Smith et al., 2006). 


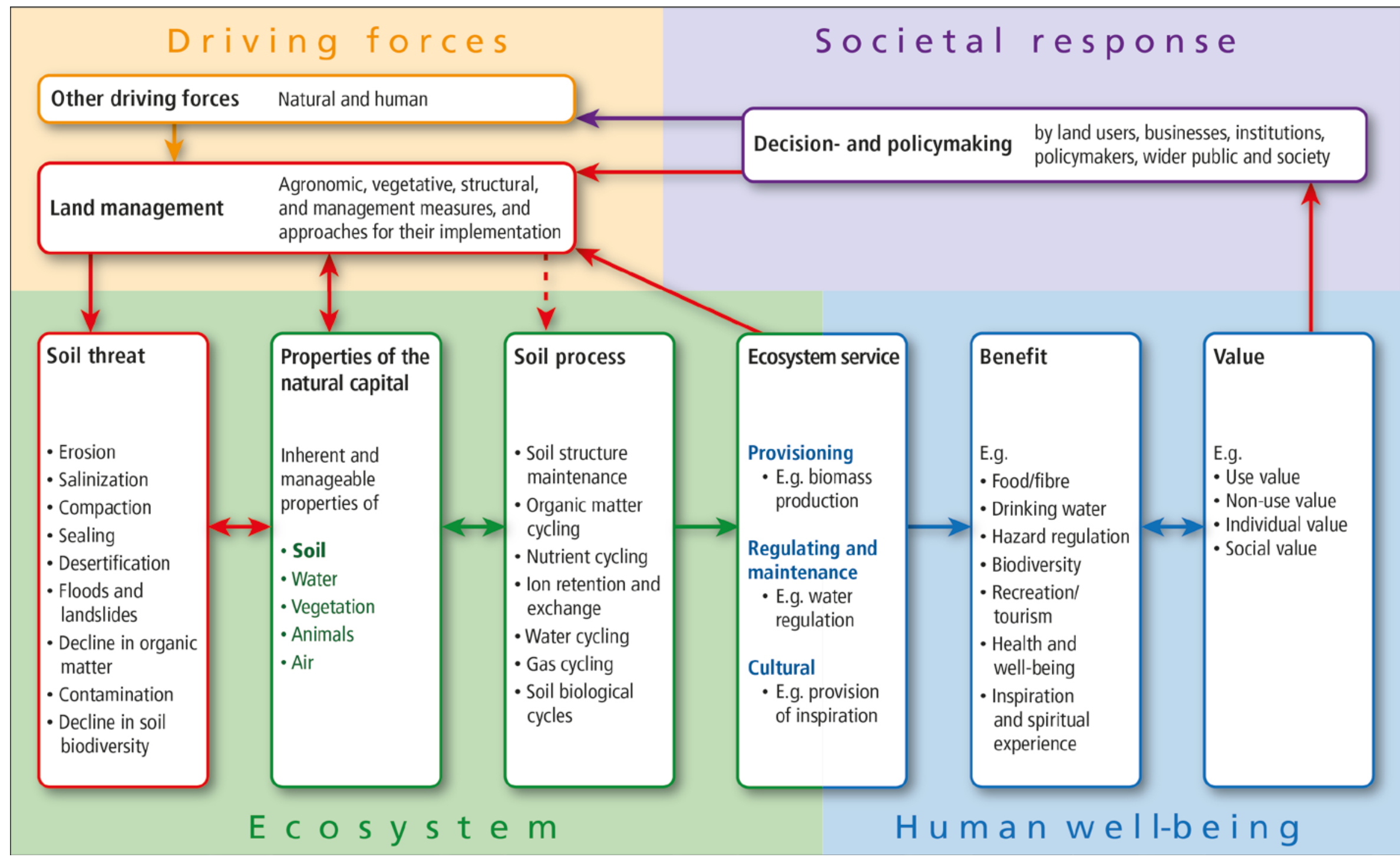

Figure 3: Proposed ecosystem services framework for RECARE. A detailed explanation is given in Sections 7 and 8. 